Luger, G. F., Stubblefield, W. A. (1998): Artificial Intelligence. Addison Wesley, USA.

Papageorgiou, A. C. (1995): Genetische Untersuchungen zur Züchtung und Generhaltung der Mittelmeerzypresse (Cupressus sempervirens L.) in Griechenland. Göttingen Research Notes in Forest Genetics 18, Georg-August Universität Göttingen, Germany.

Prata, S. (1998): $\mathrm{C}^{++}$Primer Plus, $3^{\text {rd }}$ edition. Sams Publishing, Indiana, U.S.A.
RITLAND, K. (1986): Joint maximum likelihood estimation of genetic and mating structure using open-pollinated progenies. Biometrics 42, 25-43.

Turban, E., Aronson J. (1998): Decision Support Systems and Intelligent Systems. Prentice Hall, New Jersey, USA.

Verga, A. R. (1995): Genetische Untersuchungen an Prosopis chilensis und P. flexuosa im trockenen Chaco Argentiniens. Göttingen Research Notes in Forest Genetics 19, GeorgAugust Universität Göttingen, Germany.

\title{
Seed Source Variation in Cone, Seed and Seedling Characteristic Across the Natural Distribution of Himalayan Low Level Pine Pinus roxburghii Sarg.
}

\author{
By S. Mukherjee RoY*, R. C. Thapliyal and S. S. Phartyal
}

(Received $5^{\text {th }}$ July 2004)

\begin{abstract}
The wide range of climatic condition in the natural distribution of chir pine is expected to result in high genetic variation within different populations of the species. The present study on the provenance variation of chir pine aims to determine the nature and extent of variation in wide range of populations with respect to 23 morphological traits of cone, seed and seedling, (at nursery stage) of 63 provenances of Pinus roxburghii. Seed sources exhibited a wide range of variability in terms of mean vales for various traits, standard deviation, variance, coefficient of variability, broad sense heritability, genetic advance and genetic gain and offer ample scope for undertaking screening for the desired traits. Genotypic variance $\left(\mathrm{V}_{\mathrm{g}}\right)$ and genotypic coefficient of variability $(\mathrm{GCV})$ for most of the parameters were found to be higher than corresponding environmental variance $\left(\mathrm{V}_{\mathrm{e}}\right)$ and environmental coefficient of variability (ECV), except cone fresh weight, survival\%, days taken for bud break and collar diameter where $V_{e}$ and ECV dominated the $\mathrm{V}_{\mathrm{g}}$ and GCV, thus indicating influence of environment on the expression of these traits. Moderate to high
\end{abstract}

* Forest Tree Seed Laboratory, Forest Research Institute, P.O.-New Forest, DehraDun, 248006 Uttaranchal, INDIA.

E-mail: $\underline{\text { ndroy@indiatimes.com }}$ percentage of heritability coupled with same intensity of gain, was observed for many of the traits studied under laboratory conditions and at nursery stage e.g. for germination percentage, MGT, GV. This signifies that these traits are under strong genetic control and good amount of heritable additive genetic component can be exploited for further selection and improvement of this species.

Key words: Pinus roxburghii Sarg., seed source variation, seed and seedling characters, bud break, genotypic variance $\left(\mathrm{V}_{\mathrm{g}}\right)$, genotypic coefficient of variability $(\mathrm{GCV})$, environmental variance $\left(\mathrm{V}^{\mathrm{g}}\right)$ and environmental coefficient of variability (ECV), heritability, genetic gain.

\section{Introduction}

Chir (Pinus roxburghii) is one of the five indigenous species of pine widely distributed in the outer ranges and principal valleys of Himalaya between 450-2300 m elevation, and from Afghanistan in the North-West to Arunachal Pradesh in the North-Eastern part of India between $26^{\circ} \mathrm{N}-36^{\circ} \mathrm{N}$ latitude and $71^{\circ} \mathrm{E}-93^{\circ} \mathrm{E}$ longitude. The species inhabits mostly the subtropical and warm temperature monsoon belt but occasionally can be found in areas where winter snow is a regular feature or the tropical climates where summer temperatures sometimes reach as high as $40^{\circ} \mathrm{C}$. This diverse range of climatic condition

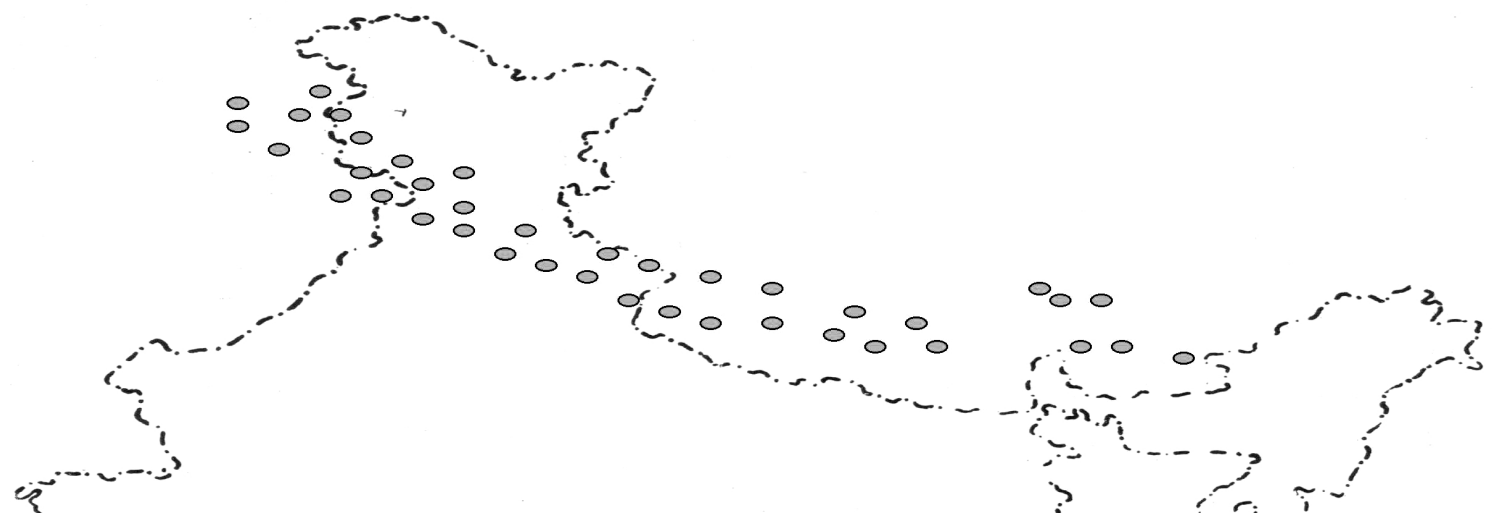

Figure 1. - Geographic distribution of Pinus roxburghii in Indian subcontinent. 
in the natural distribution of chir is expected to result in high genetic variation within different populations of the species. Provenance variation with respect to morphological, physiological and biochemical traits has been studied in chir pine (THAPLIYAL and DHIMAN, 1997) but these studies were confined to very limited number of seed sources. The present work was, therefore, taken up on $P$. roxburghii sampled drawn from wide range of distribution of the species in India from the state of Jammu and Kashmir in the north west to the Arunachal Pradesh in the north east.

Cone and seed characteristics have been shown to vary among species, provenance and genotypes in pines and are well documented by LANGDON (1958), ANDERSON (1965), KHALIL (1974), Sorensen and Miles (1978), Singh et al., (1996) and ThapliYal and Dhiman (1997). Cone size (length and width) and seed size (length, width and weight) have been used for intra-specific taxonomic distinction between population in Pinus gregii (DonAhUe and Upton, 1996), while parameters like seed weight and length are useful for classifying provenances into high and lowland groups in $P$. caribea (SALAZAR, 1986). Environmental factors in combination with genetic and physiological ones play important role in determining a forest tree's potential for seed quality, by determining its flowering threshold intensity and periodicity of flowering and fertility of seed. Thus, characters of seed quality appear under strong genetic control. Depending on the species, germination responses of seed vary according to latitude, elevation, soil moisture, soil nutrient, temperature, kind and density of plant cover and degree of habitat disturbance of the site where the seeds matured.

More recently attention has been focused on morphological and physiological characteristic of seedling to assess the field performance potential of nursery stock (BACON et al., 1977; Donald, 1982, Johnson and Cline, 1991; OMI, 1991). LAMichAHANEY (1985) found significant inter-provenance differences in Alnus nepalensis in seedling height growth, besides germination, survival in the nursery, and after planting out geographic variation for seedling characters have been studied in Pinus strobus (STEPHEN, 1974) and Juglans nigra (BEY, 1979) and in the latter was correlated significantly with latitude; southern provenances growing faster and losing their leaves later. NGULUBE (1989) found considerable genetic variation in Gliricidia sepium during nursery stage and demonstrated the importance of nursery evaluation phase in provenance elimination trials. REHMAN et al., (1988) showed significant differences among seed sources for survival in Acacia spp. and Prosopis spp. in the nursery.

Geographic variation in the time of bud initiation has been observed for several coniferous species, either from direct observation or by inference from autumn frost damage. In Sitka spruce (Picea sitchensis), the time of bud formation was closely correlated with latitude of seed origin (HAGEM, 1931; Karlberg, 1961; Aldous, 1962; Schober, 1962 and Burley, 1965). From provenance studies the order of bud bursting has been proved to be under some degree of genetic control, since the same races burst in the same relative pattern in planting site at both low and high elevation. HANOvER (1963) briefly summarized literature relating to variability in flushing response and concluded that the genetic structure of the source material may interact with a number of climatic factors to produce geographic variation in shoot growth characteristics.

The objective of the present investigation was to understand the nature, extent and pattern of variation existing in different populations of Pinus roxburghii in respect of cone, seed and seedling characters and the degree of genetic control on characters of cone and seed morphology and whether they are corre- lated with characters of seed germination and seedling growth. Such an investigation may help in early evaluation of criteria for selection of some prominent traits both in the laboratory and nursery, which may be related to subsequent performance in the field.

Table 1. - Geographic information of the seed collection localities.

\begin{tabular}{|c|c|c|c|c|}
\hline Seed source & State & Longitude & Latitude & Altitude (m) \\
\hline Mohand & UA & 77.17 & 30.18 & 675 \\
\hline August Muni & UA & 79.30 & 30.23 & 762 \\
\hline Trisula & UA & 79.15 & 30.12 & 1800 \\
\hline Nandprayag & UA & 79.50 & 30.70 & 1200 \\
\hline Birahi & UA & 79.90 & 30.90 & 1219 \\
\hline Gaucher & UA & 79.11 & 30.17 & 729 \\
\hline Bhowali & UA & 79.33 & 29.23 & 1706 \\
\hline Almora & UA & 79.40 & 29.23 & 1546 \\
\hline Ranifhet & UA & 79.25 & 29.38 & 1800 \\
\hline Kamlekh & UA & 79.47 & 29.18 & 1500 \\
\hline Gongolihat & UA & 80.02 & 29.40 & 1100 \\
\hline Askot & UA & 80.19 & 29.46 & 1387 \\
\hline Ghansali & UA & 78.39 & 30.26 & 954 \\
\hline Dharasu & UA & 78.17 & 30.37 & 650 \\
\hline Theture & UA & 78.11 & 30.30 & 1500 \\
\hline Pharsula & UA & 78.44 & 29.49 & 1300 \\
\hline Barkot & UA & 78.14 & 30.48 & 1524 \\
\hline Jarmola & UA & 78.60 & 30.57 & 1828 \\
\hline Shankri & UA & 78.50 & 31.70 & 1800 \\
\hline Thadiyar & UA & 77.55 & 30.58 & 1200 \\
\hline Darmigarh & UA & 77.38 & 30.26 & 913 \\
\hline Chiwa & UA & 77.50 & 30.57 & 1500 \\
\hline Thalisian & UA & 79.20 & 30.10 & 1500 \\
\hline Pokhara & UA & 78.50 & 29.56 & 1350 \\
\hline Diba & UA & 78.58 & 29.50 & 1600 \\
\hline Palampur & HP & 76.90 & 31.40 & 1240 \\
\hline Dharamsala & $\mathrm{HP}$ & 76.23 & 32.70 & 1250 \\
\hline Malan & $\mathrm{HP}$ & 76.43 & 32.20 & 1200 \\
\hline Baijnath & $\mathrm{HP}$ & 76.39 & 32.13 & 1125 \\
\hline Narang & $\mathrm{HP}$ & 77.25 & 30.20 & 1300 \\
\hline Rajgarh & $\mathrm{HP}$ & 77.19 & 30.51 & 1400 \\
\hline Hamirpur & $\mathrm{HP}$ & 76.30 & 32.12 & 850 \\
\hline Nadaun & HP & 76.60 & 32.20 & 650 \\
\hline Kiarla & $\mathrm{HP}$ & 77.38 & 30.55 & 1200 \\
\hline Nerwa & HP & 77.18 & 30.50 & 1250 \\
\hline Jamta & $\mathrm{HP}$ & 77.18 & 30.36 & 932 \\
\hline Banethi & $\mathrm{HP}$ & 77.16 & 30.38 & 1370 \\
\hline Dharampur & $\mathrm{HP}$ & 77.14 & 30.54 & 1500 \\
\hline Sabathu & HP & 76.59 & 30.58 & 1400 \\
\hline Suket & HP & 77.60 & 31.23 & 1830 \\
\hline Mandi & HP & 76.55 & 31.43 & 760 \\
\hline Nachan Gohar & HP & 77.05 & 31.45 & 1292 \\
\hline Manikaran & $\mathrm{HP}$ & 77.21 & 32.20 & 1737 \\
\hline Bhuntar & HP & 77.10 & 32.90 & 1100 \\
\hline Una & $\mathrm{HP}$ & 76.16 & 31.28 & 675 \\
\hline Danoghat & HP & 76.12 & 32.81 & 1100 \\
\hline Kunihar & HP & 76.36 & 30.52 & 1300 \\
\hline Kothar & HP & 76.40 & 30.50 & 1150 \\
\hline Taradevi & HP & 77.90 & 31.06 & 2205 \\
\hline Brindaban & HP & 76.33 & 31.12 & 575 \\
\hline Chamba Tikri & HP & 76.13 & 32.46 & 923 \\
\hline Bakloh & $\mathrm{HP}$ & 75.52 & 32.44 & 1350 \\
\hline Mastgarh & HP & 76.10 & 32.23 & 700 \\
\hline Jumhar & $\mathrm{HP}$ & 76.10 & 32.44 & 1100 \\
\hline Banikhet & HP & 75.40 & 32.40 & 1400 \\
\hline Bahli Taklekh & $\mathrm{HP}$ & 77.37 & 31.23 & 1300 \\
\hline Katra & $\mathrm{J} \& \mathrm{~K}$ & 74.55 & 32.58 & 520 \\
\hline Rajouri & $J \& K$ & 74.16 & 33.22 & 668.2 \\
\hline Akhnoor & J\&K & 74.42 & 32.55 & 1225 \\
\hline Noushera & $J \& K$ & 74.17 & 33.09 & 1200 \\
\hline Ramnagar & $J \& \mathrm{~K}$ & 75.18 & 32.48 & 520 \\
\hline Nafra & $\mathrm{NE}$ & 92.23 & 27.19 & 1200 \\
\hline Dhirang & $\mathrm{NE}$ & 92.15 & 27.45 & 1350 \\
\hline
\end{tabular}




\section{Material and Methods}

Seeds were sampled from 63 locations from within the natural distribution range of species in the Indian Himalayas, with considerable geographic isolation (Table 1). The area sampled ranged from $74^{\circ}-92^{\circ} \mathrm{E}$ longitude and $29^{\circ}-33^{\circ} \mathrm{N}$ latitude and from $520 \mathrm{~m}$ to $2200 \mathrm{~m}$ elevation in the state of Jammu and Kashmir (J \& K), Himachal Pradesh (HP), Uttaranchal (UA) and Arunachal Pradesh (NE). Seed at each of the location was collected from 10 average trees located about $100 \mathrm{~m}$ apart from each other in order to avoid narrowing down the genetic base due to relatedness or inbreeding, in even aged stands as per the recommended procedure (FAO 1985, TURNBULL 1975). The variation in cone and seed characteristics was investigated as under:

\section{Cone and seed characteristics}

Cone size (length and width), fresh weight and specific gravity of cone, number of scales and number of seed per cone was investigated using twenty randomly drawn undamaged cones from each of the seed sources (Table 1). The specific gravity of cone was calculated by floatation or water displacement method adapted from BARNETT (1979). From each of the seed lots representing the 63 sources, seed length and width was recorded on 20 seeds each in millimeter using an electronic vernier caliper. Seed were drawn randomly and measured for their maximum length and width in millimeter upto two decimal places using an electronic vernier caliper. Measurement of seed weight was made on the pure seed fraction of a sample, on 8 replications of 100 seeds and expressed as the 1000- seed weight. Percent moisture content (MC) of the seeds was taken up on wet basis at $103^{\circ} \mathrm{C}$ for 17 hours.

\section{Germination test in the laboratory}

Seeds were germinated in a temperature-controlled cabinet maintained at $30^{\circ} \mathrm{C}$, on top of a moist blotting paper using four replications of 100 seeds each. Seeds were considered germinated when the radicle had emerged about $1 \mathrm{~cm}$ through the coat. On $15^{\text {th }}$ day of the experiment, seedlings were measured for root and shoot length. Seed germination values were recorded and quantified as per cent germination, germination value (GV) was calculated as per procedure of CzABATOR (1962) and mean germination time (MGT) according to BONNER (1983). The root and shoot length was recorded separately using a scale up to accuracy of two decimal places on the $15^{\text {th }}$ day from the date of the start of the germination test. Observation on number of cotyledons was taken on the $15^{\text {th }}$ day by the time all the cotyledons had emerged free from the seed coat.

\section{Seedling traits (nursery)}

Nursery emergence was observed on seeds sown directly into the root trainers in the nursery. Seeds were considered germinated when the cotyledons had emerged out above the soil. Data were recorded on germination, survival, and MGT. Three seedlings per 8 replications from an individual seed source, i.e. 24 seedling in all from each of the provenance, were marked and monitored daily in the nursery till the cotyledon emerged free from the seed coat.

\section{Days taken for bud break / emergence of new flush}

Depending on the seed source a few days after the emergence of the cotyledons at the tip of the hypocotyl, surrounded by the whorl of the cotyledons a minute pin head like protuberance appeared which was green in the beginning but turned slightly pinkish mass of compact needles. The date of the appearance of this structure was considered the stage of flushing of the bud.

\section{Extension growth}

Following flushing, the length of the growing shoot was recorded for one full year at one-week interval.

\section{Statistical analysis}

Data were subjected to analysis of variance (ANOVA). Simple correlation (Karl Pearson's), and regression equation was worked out. Simple correlation was done to correlate the different traits of cone, seed and seedling with geographic distribution and a regression equation was derived for the same. The variance component, $\mathrm{V}_{\mathrm{p}}$ (phenotypic variance), $\mathrm{V}_{\mathrm{g}}$ (genotypic variance), $V_{e}$ (environment variance), coefficient of variation PCV (phenotypic coefficient of variation), GCV (genotypic coefficient of variation), ECV (environment coefficient of variation) broad sense heritability, estimated genetic advance and genetic gain were determined as suggested by BURTON and DEVANE (1953) and JoHNSON et al. (1955).

Table 2. - Simple correlation (r) between characters studied and geographical origin of the provenance of $P$. roxburghii.

\begin{tabular}{llll}
\hline Parameter & Longitude & Latitude & Altitude \\
\hline Cone Traits & & & \\
\hline Fresh Weight & $-0.30^{*}$ & -0.16 & -0.15 \\
Cone Length & -0.20 & -0.08 & -0.12 \\
Cone Width & $-0.26^{*}$ & $0.35^{*}$ & -0.12 \\
Scale No. & -0.03 & -0.15 & 0.13 \\
Specific Gravity & -0.17 & -0.13 & -0.06 \\
No. of Seed/Cone & -0.02 & $-0.44^{* *}$ & $0.25^{*}$ \\
\hline Seed Traits & & & \\
\hline 1000 Seed Weight & 0.13 & 0.10 & -0.12 \\
Seed Length & -0.19 & 0.10 & 0.04 \\
Seed Width & -0.07 & 0.03 & -0.02 \\
Moisture Content & -0.14 & $0.33^{*}$ & -0.15 \\
Lab Germination \% & 0.21 & $-0.36^{*}$ & 0.04 \\
Lab GV & 0.24 & $-0.54^{* *}$ & 0.18 \\
Lab MGT & -0.13 & $0.42^{* *}$ & -0.04 \\
Cotyledon No. & 0.04 & -0.18 & 0.22 \\
Root Length & 0.12 & -0.23 & 0.06 \\
Shoot Length & 0.07 & -0.06 & 0.01 \\
\hline Nursery Traits & & & \\
\hline Germination \% & 0.05 & $-0.35^{*}$ & 0.02 \\
MGT & -0.12 & $0.45^{* *}$ & -0.08 \\
GV & 0.10 & $-0.41^{* *}$ & 0.07 \\
Survival \% & 0.05 & -0.11 & -0.23 \\
Days taken to flush/break bud & 0.02 & $0.35^{* *}$ & 0.03 \\
One year extension growth & $0.30^{*}$ & $-0.40^{* *}$ & -0.10 \\
Collar Diameter & 0.80 & $-0.30^{*}$ & 0.23 \\
$*$ Po & & & \\
\hline
\end{tabular}

$* \mathrm{P} 0.05, * * \mathrm{P} 0.01$.

Table 3. - Variability estimates for cone, seed and seedling traits in the laboratory.

\begin{tabular}{llllll}
\hline S.No & Parameters & Range & Mean & SD & CV\% \\
\hline 1. & Cone Length $(\mathrm{cm})$ & $6.75-15.67$ & 13.06 & 1.47 & 11.25 \\
2. & Cone width $(\mathrm{cm})$ & $4.88-9.87$ & 6.53 & 0.72 & 11.02 \\
3. & Cone fresh weight $(\mathrm{g})$ & $115.22-228.02$ & 169.77 & 26.38 & 15.54 \\
4. & Cone specific gravity & $0.54-0.83$ & 0.74 & 0.06 & 8.11 \\
5. & No. of scale/cone & $68.44-112.70$ & 89.90 & 9.28 & 10.32 \\
6. & No. of seed/cone & $24.50-101.25$ & 53.79 & 17.51 & 32.55 \\
7. & 1000 seed weight $(\mathrm{g})$ & $77.22-140.43$ & 113.55 & 15.84 & 13.95 \\
8. & Seed length $(\mathrm{mm})$ & $9.34-12.71$ & 11.23 & 0.85 & 7.56 \\
9. & Seed width (mm) & $5.13-7.43$ & 3.25 & 0.45 & 6.95 \\
10. & Moisture content $(\%)$ & $4.92-10.83$ & 7.83 & 1.03 & 13.15 \\
11. & Lab germination $(\%)$ & $42.50-99.50$ & 81.43 & 14.35 & 17.62 \\
12. & Lab GV & $10.04-126.30$ & 55.21 & 27.45 & 50.00 \\
13. & Lab MGT & $4.72-12.89$ & 8.11 & 2.05 & 25.27 \\
14. & Cotyledon number & $9.75-13.00$ & 11.57 & 0.79 & 6.82 \\
15. & Root length $(\mathrm{cm})$ & $2.38-9.43$ & 5.96 & 1.32 & 22.15 \\
16. & Shoot length $(\mathrm{cm})$ & $0.78-6.83$ & 3.25 & 0.99 & 30.46 \\
\hline
\end{tabular}




\section{Results and Discussion}

Cone traits revealed significant differences among seed sources at $5 \%$ level of significance. The highest coefficient of variation was recorded for number of seed per cone (32.55) followed by for cone fresh weight (15.54) (Table 3). The difference recorded may be in response to different intensities of natural selection pressure acting upon these traits in their natural habitat. In a leguminous species the pod, seed and germination traits were considered largely under maternal influences but were strongly controlled by micro and macro habitats, besides the age and general health of the parent trees (IsIK, 1986). In the present study although any particular trend was lacking yet some of the characters correlated with geographic factors like longitude, latitude and altitude of the place of origin or collection site. Cone fresh weight and width was correlated negatively $(\mathrm{r}=-0.30$ and -0.26$)$ respectively with longitude, where- as, the cone width was correlated positively $(\mathrm{r}=0.35)$ with latitude (Table 2, Fig. 2A). Cone weight and cone width in P. roxburghii decreased towards the wetter, high rainfall north-eastern part of India, represented by Nafra and Dirang. The poor mineral level of the highly leached soils in the northeast (TRIPATHI and BARIK, 2001) probably result in inadequate supply of nutrients reflected in the stunted growth of trees and smaller size of cone as compared to relatively drier UA, HP and J \& K sources where the rainfall is limited to 3 month monsoon period and soils are rich in nutrient status. A negative correlation was found between the latitude of the seed source and number of seed per cone $(\mathrm{r}=-0.44)$ (Fig. 2B). This again reflects the effect of shorter growing period at higher latitudes. Based on the result it could be said that seed source representing semihumid regions like Dirang and Nafra of north- eastern part of India produced smaller cones containing less number of seeds.
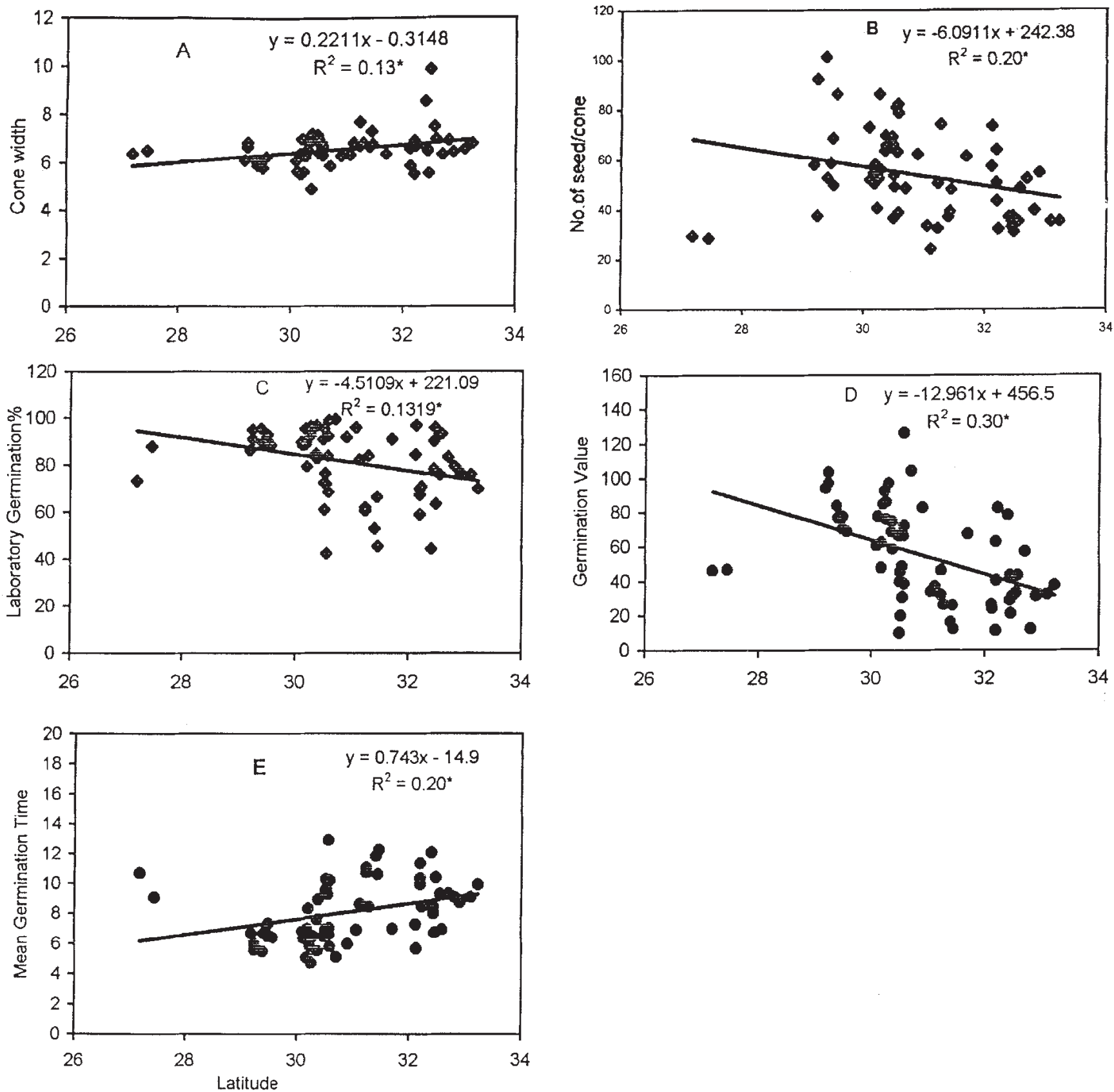

Figure 2. - Regression equation for cone width (A), Number of seed/cone (B), Lab Germination (C), GV (D) and MGT (E) with latitude. 
Table 4. - Variability estimates for seedling traits in the nursery.

\begin{tabular}{llllll}
\hline S.No & Parameters & Range & Mean & SD & CV\% \\
$\mathbf{1 .}$ & Nursery germination & $24.28-96.88$ & 68.64 & 19.50 & 28.40 \\
$\mathbf{2}$ & Nursery GV & $0.72-12.99$ & 5.76 & 3.06 & 53.12 \\
$\mathbf{3}$ & Nursery MGT & $18.14-32.53$ & 26.35 & 3.63 & 13.77 \\
$\mathbf{4}$ & Survival percent & $75.07-98.24$ & 90.76 & 5.57 & 6.14 \\
$\mathbf{5}$ & Days taken to flush/break bud & $30.00-44.00$ & 36.22 & 2.94 & 8.12 \\
$\mathbf{6}$ & Collar Diameter (cm) & $5.75-10.98$ & 7.99 & 1.31 & 16.39 \\
$\mathbf{7}$ & One year extension growth & $18.27-30.86$ & 23.99 & 3.05 & 12.73 \\
\hline
\end{tabular}

The highest phenotypic variance was found for the number of seed per cone (420.00) while the least value was recorded for cone specific gravity $(0.005)$. The genetic variance in cone traits varied from 268.40 (Number of seed per cone) to 0.003 (cone specific gravity). For the environment variance the maximum value was recorded for cone fresh weight (848.95) while the minimum value was for cone specific gravity (0.002). Genotypic variance and genotypic coefficient of variability (GCV) for most of the parameters of cones was found higher than corresponding environmental variance and environmental coefficient of variability (ECV) (Table 5). Most of the characters of cone and seed morphology were controlled very strongly by genotype of the individual trees. Environmental factors, which vary with location and populations within location, have only a small effect (KHALIL, 1974).

Table 5. - Variances and coefficient of variability for cone, seed and seedling traits.

\begin{tabular}{|c|c|c|c|c|c|c|c|}
\hline \multirow[t]{2}{*}{ S.No } & \multirow[t]{2}{*}{ Parameters } & \multicolumn{3}{|c|}{ Variances } & \multicolumn{3}{|c|}{ Coefficient of variability } \\
\hline & & $V p$ & $\mathrm{Vg}$ & Ve & PCV & GCV & ECV \\
\hline 1. & Cone Length $(\mathrm{cm})$ & 3.63 & 1.68 & 1.95 & 14.60 & 10.00 & 10.69 \\
\hline 2. & Cone width $(\mathrm{cm})$ & 0.82 & 0.42 & 0.40 & 13.86 & 9.97 & 9.60 \\
\hline 3. & Cone fresh weight (g) & 1333 & 484 & 848.95 & 21.51 & 12.95 & 17.16 \\
\hline 4. & Cone Specific gravity & 0.005 & 0.003 & 0.002 & 9.55 & 7.40 & 6.04 \\
\hline 5. & No. of Scale/cone & 136.36 & 69.41 & 67.22 & 13.00 & 9.30 & 9.12 \\
\hline 6. & No. of seed/cone & 420.00 & 268.40 & 152.046 & 38.12 & 30.42 & 22.92 \\
\hline 7. & 1000 seed weight $(\mathrm{g})$ & 282.00 & 240.00 & 41.92 & 15.00 & 13.60 & 5.70 \\
\hline 8. & Seed length $(\mathrm{mm})$ & 1.500 & 0.50 & 1.03 & 10.90 & 6.30 & 9.03 \\
\hline 9. & Seed width (mm) & 1.100 & 0.75 & 0.32 & 16.23 & 13.41 & 8.75 \\
\hline 10. & Moisture content & 1.400 & 0.95 & 0.43 & 15.11 & 12.45 & 8.74 \\
\hline 11. & Lab germination (\%) & 232.60 & 197.11 & 35.45 & 18.73 & 17.24 & 7.31 \\
\hline 12. & Lab GV & 817.50 & 732.0 & 85.74 & 52.00 & 49.00 & 16.77 \\
\hline 13. & Lab MGT & 4.54 & 4.20 & 0.34 & 26.40 & 25.40 & 7.22 \\
\hline 14. & Cotyledon number & 1.00 & 0.50 & 0.50 & 8.70 & 6.12 & 6.12 \\
\hline 15. & Root length $(\mathrm{cm})$ & 2.83 & 1.40 & 1.43 & 28.23 & 19.85 & 20.06 \\
\hline 16. & Shoot length $(\mathrm{cm})$ & 1.63 & 0.77 & 0.86 & 39.34 & 27.04 & 28.60 \\
\hline
\end{tabular}

\section{Seed traits}

Seed traits viz., seed length, width, weight and moisture content varied significantly among seed sources. Seed size may vary due to both internal (maternal, hereditary) and external (environmental) conditions operating at the time of seed development (HARPER et al., 1970). This differential development might have an adaptive advantage in local edapho-climatic condition. In the present study, though the above-mentioned characters are significantly different between seed sources yet they do not show any particular trend with longitude, latitude or altitude. Variation in P. roxburghii seed sources with respect to their morphological characters could be due to the fact that this species grows over a wide range of climatic conditions. Marked differences in selection pressure must have affected the structure of population. Such variations in relation to habitat have also been reported in Acacia nilotica (BAGCHI et al., 1990), Dalbergia sisoo (Gera et al., 2000, Devagiri, 1997), Acacia catechu (RAMACHANDRA, 1995), Pinus bungea (WANG et al., 1998).

The consideration of seed weight in the delineation and understanding the geographical variation has been advocated because of the least plasticity of this character (HARPER et al.,
1970). In the present study the maximum seed weight (140.43 g) was observed for Birahi (UA) which is approximately double to seed weight (77.4 g) recorded for Chopal Kiarla (HP). Though there is a large variation in seed weight of $P$. roxburghii yet it is not correlated with any geographic factor mentioned earlier. In the case of seed dimension i.e. seed length and seed width, however, very little variation was found. Maximum values for seed length $(12.71 \mathrm{~cm})$ and seed width $(7.43 \mathrm{~cm})$ was recorded for Una (HP) and Supin Sakhri (UA) respectively. Minimum seed length $(9.34 \mathrm{~cm})$ was in Chopal Kiarla (HP) and least width $(5.13 \mathrm{~cm})$ was recorded for Bahli Taklekh (HP). Since the seeds were collected from different locations, from trees approximately of the same age, differences observed in seed parameters may be attributed to the different genetic architectures developed as a result of adaptation to diverse environmental condition prevailing throughout their distributional range (SALAZAR and QUESDA, 1987).

Table 6. - Estimate of Genetic component for cone, seed and seedling traits in laboratory condition.

\begin{tabular}{cllll}
\hline S.No & Parameters & Heritability & Genetic Advance & Genetic Gain (\%) \\
\hline 1. & Cone Length $(\mathrm{cm})$ & 46.28 & 1.81 & 13.90 \\
2. & Cone width $(\mathrm{cm})$ & 52.00 & 1.00 & 15.31 \\
3. & Cone fresh weight $(\mathrm{g})$ & 36.31 & 27.08 & 16.00 \\
4. & Cone Specific gravity & 60.00 & 0.08 & 11.69 \\
5. & No. of Scale/cone & 47.14 & 11.31 & 12.60 \\
6. & No. of seed/cone & 64.00 & 28.00 & 50.25 \\
7. & 1000 seed weight $(\mathrm{g})$ & 85.12 & 29.42 & 25.83 \\
8. & Seed length $(\mathrm{mm})$ & 33.33 & 0.83 & 7.40 \\
9. & Seed width $(\mathrm{mm})$ & 68.20 & 1.50 & 23.22 \\
10. & Moisture content & 67.86 & 1.66 & 21.20 \\
11. & Lab germination $(\%)$ & 84.74 & 26.38 & 32.40 \\
12. & Lab GV & 89.54 & 52.42 & 94.96 \\
13. & Lab MGT & 93.00 & 4.08 & 50.50 \\
14. & Cotyledon number & 50.00 & 1.03 & 8.91 \\
15. & Root length $(\mathrm{cm})$ & 49.50 & 1.70 & 28.52 \\
16. & Shoot length $(\mathrm{cm})$ & 47.24 & 1.23 & 37.84 \\
\hline
\end{tabular}

\section{Seed viability and vigour}

Seed germination and vigour in terms of mean germination time and germination value were found negatively correlated with latitude (Table 2, Fig. 2C-E). This shows that as the latitude decreases from north to south the germination per cent increases and it takes lesser time (MGT) for the seed to germinate. This observation could be explained on the basis that as we proceed towards lower latitudes there is a progressive increase in the length of the growing season. With the increase in growing period there is also an increment in nutrient assimilation rate finally resulting in the accumulation of more stored food material. KHALIL (1986) reported somewhat similar results in the seeds of Picea gluaca and PITCHER (1984) in black cherry (Prunus serotina), where they found a north-south trend in the seed. The seed vigour, i.e. germination value exhibited the largest value of GCV (49.00) with wide range (10.24-126.20) and $51.52 \%$ of coefficient of variation (Table 3 and 5 ). In case of the seed trait GV the maximum values for phenotypic, genotypic and environmental variance were recorded and the corresponding values for the same were 817.50, 732 and 85.74 respectively. Genotype has very strong influence on vigour of the seed (SCHMIDT, 2000).

\section{Seedling traits (nursery)}

Nursery data (Table 2) exhibits that germination per cent $(\mathrm{r}=-0.35)$ and MGT $(\mathrm{r}=0.45)$ is correlated with latitude of the seed origin $(F i g .3 F-H)$. These characters varied over a latitudinal cline. Highest germination per cent was revealed by seed sources in the range of $29^{\circ} \mathrm{N}$ to $30^{\circ} \mathrm{N}$ whereas at higher latitudes viz. $31^{\circ} \mathrm{N}$ to $33^{\circ} \mathrm{N}$ there was a gradual decline in the 
value of this trait. The MGT of higher latitude seed sources, was also higher i.e. required more time for germination to complete. Seedling from southern latitude and medium altitude generally grow faster than those from northern latitude and higher altitude. Seed sources differed significantly with respect to nursery germination, bud flushing, extension growth and collar diameter. Present study revealed that the growth parameters have strong positive relationships with seed size and weight and seed vigour has significant influence on germination and subsequent plant growth. Seedlings of different seed sources when grown under common nursery environmental conditions often display different patterns of shoot growth (DorMLing, 1979; REHFELDT and WyCOFF, 1981 and SoRENSEN, 1979). In the present investigation, where seeds of all seed
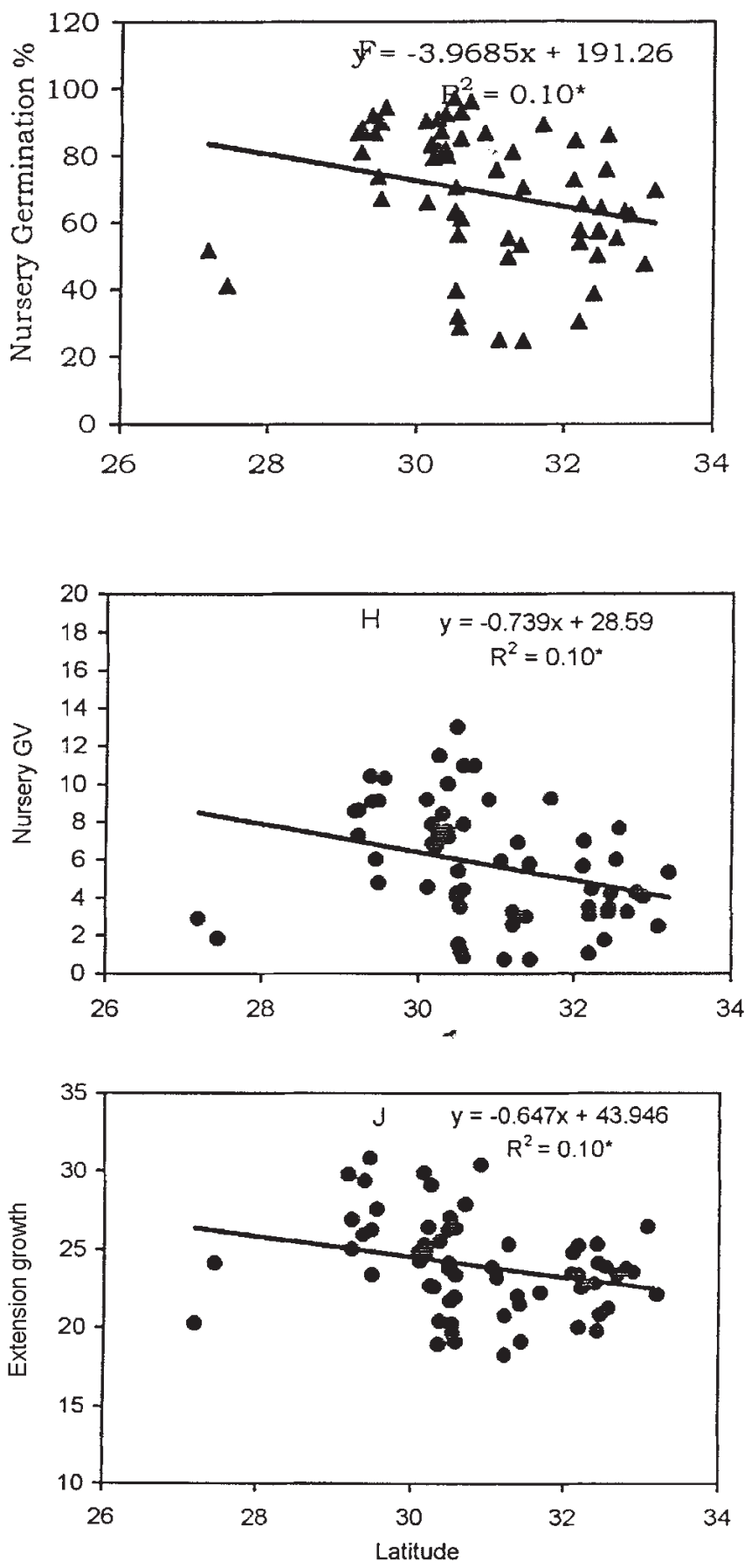

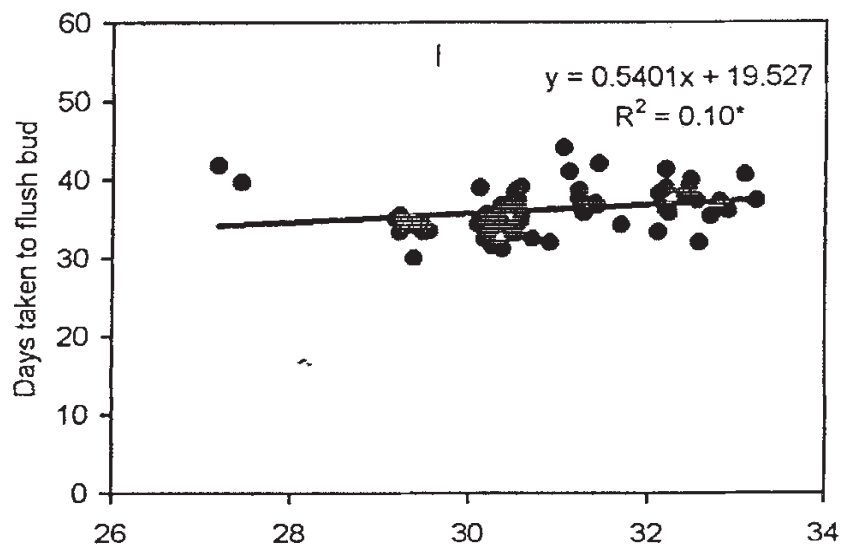

sources were raised under identical nursery conditions, the environmental influences are expected to have been reduced to minimal, therefore, variation among seed sources in nursery emergence and growth could be interpreted as genetic.

The estimates of variability with regard to genetic parameters studied at nursery stage viz, germination, MGT, survival, days taken to break bud, collar diameter and extension growth depicted wide range of variation. The phenotypic, genotypic and environmental variance was exhibited highest for germination i.e., 480.56, 366.00, 114.56 respectively (Table 7). $\mathrm{V}_{\mathrm{g}}$ and GCV dominated the $\mathrm{V}_{\mathrm{e}}$ and ECV in case of nursery germination $\%$, MGT, whereas survival per cent, bud initiation and collar diameter is more affected by $\mathrm{V}_{\mathrm{e}}$ and ECV. From the present study it is evident that the days taken to break bud is positive-
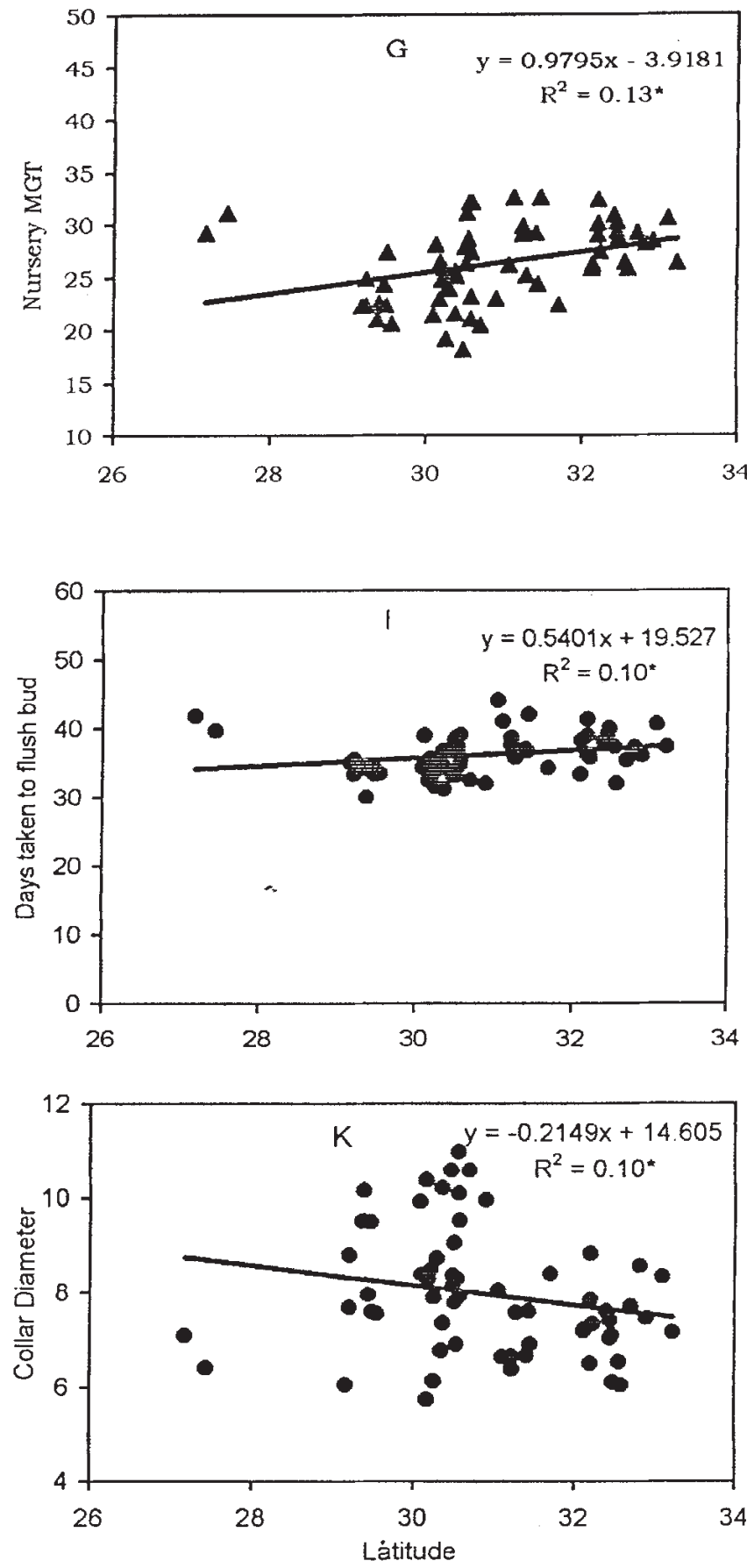

Figure 3. - Regression equation between Nursery germination percent (F), MGT (G), GV (H), Days taken to flush bud (I), extension growth (J) and collar diameter $(\mathrm{K})$ with latitude. 
ly correlated with latitude of seed origin $(\mathrm{r}=0.35)$ (Fig. 3I). Yet the environment plays an important role in the bud-flushing pattern, it has been suggested that bud break may be a physiological indicator of seedling vigour and thus a useful predictor of field survival (LAVENDER, 1985). The present investigation shows that development of the bud followed a continuous, welldefined pattern, provenances differ in the time of bud flushing. Bud formations though influenced by different factors, were recognized as adaptation to the climatic conditions in the native regions (BURLEY, 1965). Geographic variation in the time of bud formation has been reported for many conifers. In Sitka spruce, the time of bud formation is closely correlated with latitude of seed origin. (HAGEM, 1931; KARLBERG, 1961; Aldhous, 1962; Schober, 1962 and Burley, 1965.) As we move towards lower latitude growing season increase with decreasing latitude. Bud flushing is controlled largely by day temperature and time of flushing reflects the nature of temperature regime in the native habitat (BURLEY, 1965a). Because some species extend over wide latitudinal range, they may be expected to show intraspecific variation in response to day length. Present investigation revealed that seed emanating from sources located at higher latitude (Table 1) viz. Rajouri (J \& K), Noushera (NE), Bhuntar (HP), took 37.30, 40.62, and 36.06 days respectively for the flushing of bud whereas seed sources from lower latitude viz. Gongolihat (UA), Dharasu (UA) and Darmigad (UA) took 30, 31.2 and 31 days for the flushing of bud. Extension growth is also correlated with bud flushing $(\mathrm{r}=-0.51)$. The height attained at the end of the growing season was demonstrated to be related to date of bud break and latitude of seed origin, In the present investigation extension growth recorded after 12 month exhibited a N-S trend, i.e. negative correlation with latitude $(\mathrm{r}=-0.40)($ Fig. $3 J)$ this was perhaps due to seed sources from the lower latitude being adapted to longer continued growth starting in early autumn and continuing into late summer leading to greater height than seeds sources from the northern latitudes. Collar diameter is negatively correlated $(\mathrm{r}=-0.30)$ with latitude (Fig. $3 K)$ but was highly positively correlated with seed and seedling vigour. Seed sources, which germinated first and exhibited better adaptation to the local environment, tended to show greater collar diameter as compared to seed sources that had less vigorous seeds.

Heritability values were found over 50 per cent for most of the traits of cone, seed, and seedling (nursery) except cone length, cone fresh weight, number of scale/cone, seed length, shoot length, number of days taken for bud break, survival per cent and collar diameter (Table 6 and 8 ). However, moderate to high percentage of heritability coupled with same intensity of

Table 7. - Variances and coefficient of variability for seedling traits in the nursery.

\begin{tabular}{llllllll}
\hline S.No & Parameters & \multicolumn{3}{l}{ Variances } & \multicolumn{3}{c}{ Coefficient of variability } \\
\cline { 3 - 8 } & & $\mathbf{V p}$ & $\mathbf{V g}$ & $\mathbf{V e}$ & PCV & GCV & ECV \\
\hline 1. & Nursery germination & 480.56 & 366 & 114.56 & 32.00 & 27.87 & 16.00 \\
2. & Germination value & 11.87 & 9.00 & 2.87 & 60.00 & 52.1 & 29.40 \\
3. & Mean germination time & 15.86 & 12.80 & 3.06 & 15.11 & 14.00 & 7.00 \\
4. & Survival percent & 129.12 & 17.12 & 112 & 12.52 & 4.55 & 11.66 \\
5. & Days taken to flush/break bud & 18.30 & 6.00 & 12.30 & 12.00 & 7.00 & 10.00 \\
6. & Collar Diameter & 5.00 & 1.26 & 3.74 & 28.09 & 14.10 & 24.29 \\
7. & One year extension growth & 14.53 & 8.40 & 6.13 & 15.91 & 12.09 & 10.33 \\
\hline
\end{tabular}

Table 8. - Estimate of genetic component for seedling traits in nursery condition.

\begin{tabular}{lllll}
\hline S.No & Parameters & Heritability & Genetic Advance & Genetic Gain (\%) \\
\hline 1. & Nursery germination & 76.16 & 34.32 & 50.00 \\
2. & Germination value & 76.00 & 5.40 & 94.00 \\
3. & Mean germination time & 81.00 & 7.00 & 26.55 \\
4. & Survival percent & 13.25 & 3.10 & 3.41 \\
5. & Days taken to flush/break bud & 33.00 & 3.00 & 8.30 \\
6. & Collar Diameter & 25.00 & 1.20 & 14.61 \\
7. & One year extension growth & 58.00 & 4.55 & 19.00 \\
\hline
\end{tabular}

gain, was exhibited by many of the traits viz., lab MGT, GV, nursery germination, GV and MGT. This signifies that these traits are under strong genetic control and good amount of heritable additive genetic component can be exploited for further selection and improvement in this species. The effectiveness of selection is dependent upon the variability present in the germplasm and the extent to which it is heritable (DUDLEY, 1997). $33 \%$ of heritabitlity accompanied by very little genetic gain of $8.30 \%$ reveals the fact that bud flushing though influenced by different factors, were recognized primarily as adaptations to the climatic condition in the regions were they have been planted (BURLEY, 1965). Extension growth revealed 58\% heritability but coupled with very low genetic gain of $19 \%$. Similar results were also observed for cone and seed dimensions, cone fresh weight, number of scale/cone, and cotyledon number and survival per cent. Despite high heritability, these traits did not show expected high genetic gain and it can be said to have more of non-additive genetic effects than additive genetic effects. JoHNSON et al. (1955) observed that high heritability estimate along with high genetic gain is usually more useful than the heritability values alone in predicting the resultant effect from selecting the best individuals from best provenances. Thus most of the characters of cone and seed morphology were controlled very strongly by genotype of the individual trees.

\section{Conclusion}

Some of the prominent traits of cone, seed and seedling revealed clinal pattern of variation i.e. N-S trend. Environmental factors, which vary with location and populations within location, have only a small effect. The seed viability and vigour i.e. germination per cent, MGT, GV, root/shoot length exhibited the highest value of GCV than ECV. Genotype has very strong influence on viability and vigour of the seed. The extent of genetic control over germination in coniferous seeds has been reported to be high due to the high proportion of the maternal effect in their seed structure. Estimates of variability and genetic parameter for nursery study in different traits depicted wide range of variation. $\mathrm{V}_{\mathrm{g}}$ and GCV dominated the $\mathrm{V}_{\mathrm{e}}$ and ECV in case of nursery germination\%, MGT whereas survival percent, time of flushing of bud and collar diameter is affected more by $\mathrm{V}_{\mathrm{e}}$ and ECV thus indicating influence of environment on the expression of these characters. Moderate to high per cent of heritability coupled with same intensity of gain, was exhibited by the traits viz., MGT, GV recorded in the laboratory and nursery conditions. This signifies that these traits are under strong genetic control and can be exploited for further selection and improvement of this species.

\section{Acknowledgement}

The authors would like to acknowledge USDA for the financial grant.

\section{Literature}

ALDHOUS, J. R. (1962): Provenance of Sitka spruce: an account of nursery stage of experiments sown in 1958. In: UK For. Comm. Rep. For. Res., 1960/61, pp. 147-154.

ANDERson, E. (1965): Cone and seed studies in Norway spruce (Picea abies (L.) Karst.) Stud. For. Suecica, No. 23.

BACON, G. J., Hawkins, P. J. and JeRmyn, D. (1977): Morphological grading studies with 1-0 slash pine seedlings. Aust. For. 40 (4): 293-303.

BAGCHI, S. K., Joshi, D. N. and RawAT, D. S. (1990): Variation in seed size of Acacia spp. Silvae Gen. 39 (3-4): 107-110.

BARNETT, J. P. (1979): An easy way to measure cone specific gravity. In: KarRfalt, R. P., Comp. Proceedings of the seed collection workshop, 1979 May 16-18. Macon. G.A. SA-TP-8. Atlanta G.A: US Dept. of Agri. For. Serv., State and Priv. Forestry, 21-23. 
BEY, C. I. (1979): Geographical variation in Juglans nigra in the mid western United States. Silvae. Genet. 28 (4): 132-135.

BonNER, F. T. (1983): Germination responses of loblolly pine to temperature differentials on a two-way thermogradient plate. J. Seed Technology 8(1): 6-14.

BuRley, J. (1965a): Genetic in seed characteristics of Sitka spruce, Adv. Front. Plant Sci. (New Delh) 10: 11-24.

Burley, J. (1965): Genetic variations in Picea sitchensis (Bong.) Cars. - A literature review. Commonw. For. Rev. 44 (1): 47-59.

Burton, G. W. and Devane, E. W. (1953): Estimating heritability in tall Festuca arundinacea from replicated clonal material. Agron. J. 4: 78-81.

CZABATOR, F. J. (1962): Germination Value: an index combining speed and completeness of pine germination. Forest Science 8: 386-396.

DevagiRI, G. M. (1997): Evaluaton of seed source variation in seed and seedling traits in Dalbergia sissoo Roxb. Ph.d. Thesis, FRI Deemed Univ., Dehradun, India, pp. 189.

DonAHUE, J. K. and Lopez-UPTON, J. (1996): Geographical variation in leaves, cone and seeds of Pinus gregii in native forests. For. Ecol. Manage. 82: 145-157.

DonALD, D. G. M. (1982): Plant characteristics affecting survival and early growth. 221-223 Sept., Mededeling Communication 98 (1).

DoRMLING, I. (1979): Influence of light and temperature on photoperiodic response of Norway spruce provenances. I: Proc. IUFRO Norway spruce Meeting Bucharest, pp 398-408.

DuDLEY, J.W. (1997): Quatitative genetics and plant breeding. Adv. in Agrnomy 59, 1-23.

F.A.O. (1985): A guide of forest seed handling: with special reference to tropics. FAO forestry paper No. 20/2, FAO, Rome, p. 379 .

Gera, N., Gera, M and Purohit, M. (2000): Source variation in seed and germination characteristics in Acacia nilotica Willd. Ex Del. Seed Research. 28 (1), 27-31.

HAGEM, O. (1931): Forsok med vestamerikanske traeslag (Experiments with west American tree species). Medd. Vestl. Forstl. Forsoks. 4 (2), No. 12. 217pp.

HANOveR, J. W. (1962): Geographical variation in Ponderosa pine leader growth. For. Sci. 9: 86-95.

Harper, J. L., Lovell, P. H. and Moore, K. G. (1970): The shapes and sizes of seeds. Ann. Rev. Ecol. Syst. 11: 327-356.

InGRAM, C. L. (1984): Provenance research on Pinus elliottii Englemann and P. taeda Linn is Malawi. In: Provenance and genetic improvement stratgies in tropical forest trees. BARNES, R. D. and Gibson, G. L. (eds.) Proc. Jt. Work. Conference, IUFRO Mutare, Zimbabwe, pp. 265-277.

IsIK, K. (1986): Altitudinal variation in Pinus brutia Ten: seed and seedling characteristics. Silvae Gen. 35 (2-3): 58-67.

ISTA (1993): International Rules for Seed Testing. International Seed Testing Association. Seed Sci. \& Technol. 21.

Johnson, H. W., Robinson, H. F. and Comstock, R. F. (1955): Estimates of genetic and environmental variability in soyabean. Agron. J. 47: 314-318.

Johnson, J. D. and Cline, M. L. (1991): Seedling quality of southern pine. In: Dureaya, M. L. and Dougherty, P. M. (EDS). Forest Regeneration Manual, 143-159. Kluwer Academic Publishers: Dordrecht/Boston/London.

KARLBERG, S. (1961): Development and yield of Douglas Fir (Pseudotsuga taxifolia (Poir.) Britt.) and Sitka spruce (Picea sitchensis (Bong.) Carr.) In Southern Scandinavia and on the Pacific Coast, Roy. Sch., Stockholm, Bull. 34, 141pp.

KHALIL, M. A. K. (1974): Genetics of cone morphology in white spruce (Picea glauca). Can. J. Bot. 52: 15-21p.

KHALIL, M. A. K. (1986): Variation in seed quality and some Juvenile characters of white spruce (Picea glauca Moeneu Voss). Silvae Gen. 35 (2-3): 78-85.

Kraus, J. F., Wells, O. O. and Sluder, E. R. (1984): Review of provenance variation in loblolly pine (Pinus taeda L.) in the southern United States. In: Provenance and genetic improvement strategies in tropical forest trees. BARNESS, R. D. and GIBson, G. L. (eds). Proc. Jt. Work. Conference, IUFRO, Mutare, Zimbabwe. Pp. 281-317.

LAMICHHANEY, B. P. (1985): Variation of Alnus nepalensis D. Don. In Nepal. Summer trail at Pakhribas (Dhankuta) Nepal Forestry Technical information Bullentin (NEFTIB). Forest
Research and Information Centre, Forest Survey and Research Office, Department of Forest, Nepal 11: 10-15.

LANGDON, O. G. (1958): Cone and seed size of south florida slash pine and their effect on seedling size and survival. Jour. For. 56: 122-127.

LAVEnder, D. P. (1985): Bud dormancy. In: Dureaya, M. L. (Ed). Evaluation Seedling Quality: Principles, Procedures and Predictive Abilities Of Major Test, pp. 7-15. For. Res. Lab., Ore State Univ., Corvallis, Oregon.

OMI, S. K. (1991): The target seedling and how to produce it. In: Texas Forest Service. Proc. from the nursery management workshop. Sept. 10-12, Alexandria, LA. Texas Forest Service, Reforestation Department, College station. Texas. pp. 88-118.

NGUlube, M. B. (1989): Genetic variation in seed germination and seedling growth of 24 Gliricidia sepium provenances. For. Ecol. Manag. 28 (1): 1-6.

PITCHER, J. A. (1984): Geographic variation patterns in seed and nursery characteristics of black cherry. USDA For. Serv. Res. Pap., Southern For. Expt. Sta., No. SO-208, p. 8.

RAMACHANDRA, N. G. (1996): Provenance variation in seed and seedling parameters in Acacia catechu Will. Ph. D. Thesis, FRI-Deemed University, DehraDun.

REHFELDT, G. E. (1994): Adaptation of Picea engelmannii population to the heterogenous enviroments of the intermountain west. Can. J. Bot. 72: 1197-1208.

REHFELDT, G. E. and WyCOFF, W. R. (1981): Periodicity in shoot elongation among populations of Pinus contorta from the northern Rocky Mountain. Ann. Bot. 48: 371-377.

ReHMAN, S., Hussain, A. and AMEen, S. (1988): Results of colony selection of Acacia and prosopis spcies/seed sources. Pak. J. For. 38 (2): 109-117.

SALAZAR, R. (1986): Genetic variation in seeds and seedling of ten provenances of Gliricidia sepium (Jacq.) Stend. For. Ecol. Manag. (1-4): 391-401.

SAlAZAR, R. and QuesadA, M. (1987): Provenance variation in Guazuma ulmifolia L. in Costa Rica. Commonwealth For. Rev. 66 (4): 317-324.

SCHMIDT, L. (2000): Guide to handling of tropical and sub tropical forest seeds. Danida forest seed centre. Krogerupvej. 21.

ScHOBER, R. (1962): Die Sitka-Fichte. Schrift. Forst. Fak. Univ. Gottingen 24/25: 230p.

Singh, V., SAH, V. K., BANA, O. P. S. and Singh, V. (1996): The effect of cone diameter on seed yield, moisture content and germination in Himalayan blue pine (P. wallichiana B. B. Jacks). Ind. For. 122: 150-154.

Sorensen, F. C. (1979): Provenance variation in Pseudotsuga menziesii seedlings from the var. menziesii and var. glauca transition zone in Oregon. Silvae Gen. 28: 96-103.

Sorensen, F. C. and Miles, R. S. (1978): Cone and seed weight relationship in Douglas-fir from western and central region. Ecology. 59 (4): 641-644.

STEPhan, B. (1974): Geographical variation in Pinus stobus on the basis of preliminary results of field trial in lower Saxony. Silvae Gen. 23: 6, 214-220 10 ref.

Thapliyal, R. C. (1986): A study of cone and seed in Pinus roxburghii Sarg. J. Tree. Sci. 5(2) 131-133.

Thapliyal, R. C. and DHiman, R. C. (1997): Geographic variation in seed and seedling characteristics in Pinus roxburghii sarg. From Himachal Pradesh. Ann. For. 5 (2): 140-145.

TRIPATHI, R. S. and BARIK, S. K. (2001): North-east ecoregion biodiversity strategy and action plan Submitted to: Ministry of Environment and Forests Government of India New Delhi.

TURNBULL, J. W. (1975): Seed collection - sampling consideration and collection tech. In: report of FAO/DANIDA training course of forest seed collection on handling held in Chiang Mai, Thailand, Feb/March, FAO/TF/RAS-11(DEN), FAO, Rome.

Wang, G., Arnold, R. J., Gardiner, C. A., Zhang, I. and Wu, Z. (1999): Seed source variation for growth in Eucaltptus dunnii; results from trial in south central China. Australian Forestry 62 (2): 125-137.

WANG, Xiaoping; LiU, Jinglan; WANG, JiUlin; LiU, ChUnJIANG; WANG, X.P.; LIU, J.L.; WANG, J.L. and LIU, C.J. (1998): Geographical variation of the morphological characteristics of Pinus bungeana seeds and cones. Journal of Beijing Forestry University 20: 3, 25-31: 15 ref. 